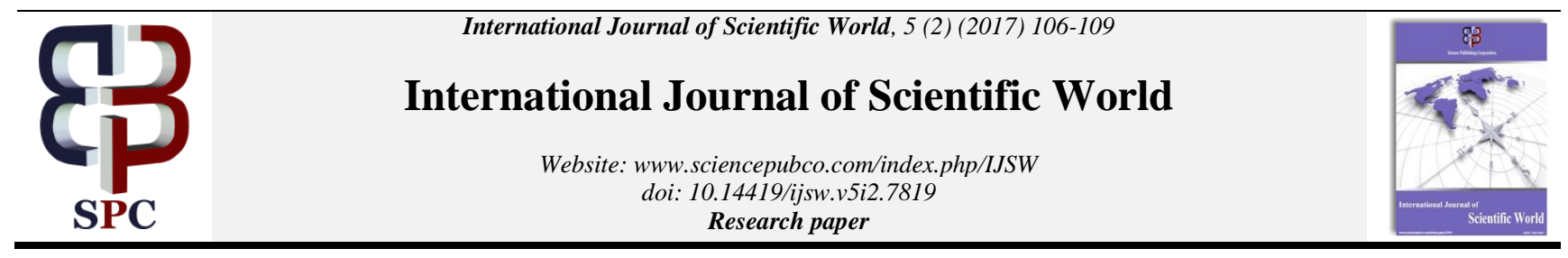

\title{
Economics of Maize (Zea mays L.) Production in Nigeria and Maize Traditional Utilization
}

\author{
Monday Sunday Adiaha* \\ Department of Agronomy (Crop and Soil Science), Faculty of Agriculture and Forestry, Cross River University of Technology, Nigeria \\ *Corresponding author E-mail: mondaysadiaha@gmail.com
}

\begin{abstract}
A survey on economics of Maize (Zea mays L.) production in Nigeria and its traditional utilization was conducted. Result of the survey presented maize having the potential of increasing the economy of the nation. Analyzed data presented maize been able to increase the income of the local people and foreign exchange earnings, as observed where price of the crop during 1980 (2500) stands below price at 1989 (14000). Increased in land utilization with increase in years was observed in data analyzed as 1980 (95600 hectares) of land area stands below (211740) in1989. Traditional utilization of maize has been found to include where the crop is been used as herbal medicine, as food, in traditional religion, in-addition to where the crop is been utilized in marital rituals.
\end{abstract}

Keywords: Economics; Maize, Zea Mays; Land Utilization; Maize Production; Maize Utilization.

\section{Introduction}

Utilization of crops has always improved Man's economy from time immemorial. Maize (Zea mays L. Poaceae) ranks $3^{\text {rd }}$ after wheat and rice, owing to the large areas and total production output of the crop [1], [2]. The crop was introduced into Nigeria probably by the Portuguese [2]. Maize is also called corn. In Nigeria, the crop is called with many vernacular names 'agbado' (Yoruba), 'ibokpot' (Efik) and 'masar' (Hausa). The crop is extensively cultivated in United States with about 50\% production [3], [4], [1]. Annual maize production at about 5.6 million hectares out of 9 million hectares in Africa has been reported by Hartmans [5] to be cultivated to maize in Nigeria. Data of IITA [6] reported 8 million tons of maize been produced in Nigeria.

Agriculture has always been a means of foreign exchange earnings. Intensive production of crops like maize enhance or improve the economy of the country. Production of maize in Nigeria has increase the income of smallholder farmers, serving as a local cash crop [7]. Intensive production of maize has been viewed as a measure of reducing hunger while combating global food insecurity.

Maize is utilized in a variety of ways, depending on the user's need. In Nigeria the crop can be used as food, as herbal medicines as well as feed ingredient in livestock management. Maize can be consumed as food by boiling or roasting as paste. Several traditional uses of maize have been reported, and this varies according to localities or ethnic groups. This investigation seeks to examine the economics of maize production in Nigeria and the traditional utilization of the crop.

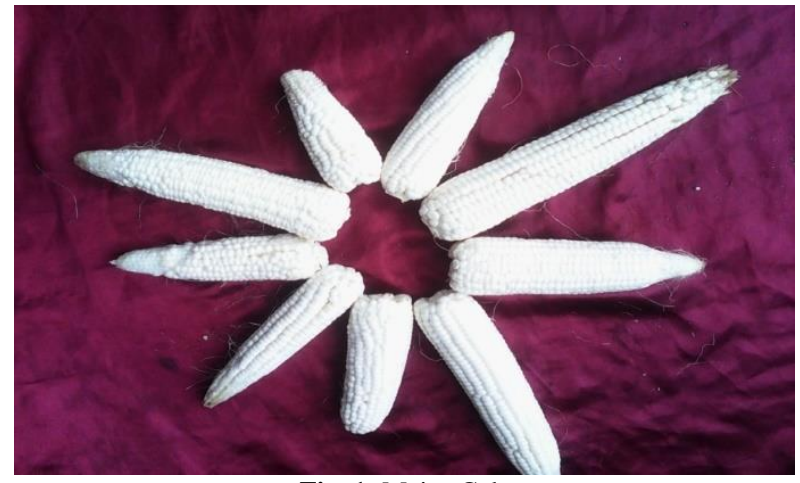

Fig. 1: Maize Cob.

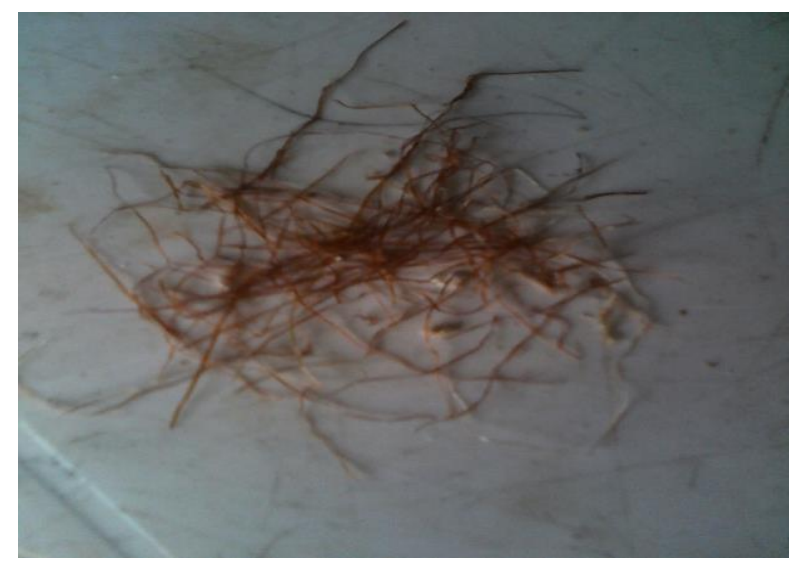

Fig. 2: Corn Silk. 


\section{Materials and methods}

\subsection{The study location}

The study was carried out in Obubra, southern Nigeria, location of the Faculty of Agriculture and Forestry, Cross River of Technology(CRUTECH), Nigeria, Obubra is on latitude $6^{\circ} 06^{\prime} \mathrm{N}$ and longitude $8^{\circ} 18^{\prime} \mathrm{E}$ in the rainforest zone of Nigeria. Obubra is characterized by a mean annual rainfall distribution at $2250 \mathrm{~mm}-2500 \mathrm{~mm}$ with annual temperature range at $25^{\circ} \mathrm{C}-27^{\circ} \mathrm{C}$.

\subsection{Methodology}

Oral interview on uses of maize in Obubra was carried out. Field cropping was done, using (Ikom Local White Maize variety). Field trip to different areas where maize is utilized traditionally was undertaken alongside close observation of local people who were given large quantities of maize. Data on maize production trend, total grain production, percentage of maize grain, area of land devoted to maize cultivation and price of maize was obtained from Central Bank of Nigeria, CBN [8], from 1980 to 1989. And consultation of relevant research findings literature was the methods used in collection and collation of data for this investigation.

\section{Results and discussions}

Result of analysis of data indicated a huge income been generated from maize production, management and sales, thereby agreeing with the findings of Ayeni [7], where the researcher stated maize been used as a local 'cash crop' for income generation as observed in the price of Maize from 1980 to 1989, as presented in (Table 1). The average of all the data analyzed indicated increased in the land area devoted to maize cultivation, thereby confirming the research findings of Hartmans [5], which presented Nigeria to be the highest producer of the crop in Africa. The analysis also presented the fact that, as the year doubles, more land area are been put into maize cultivation, owing to the ability of the crop to be able to strive in all agro-ecological zones of the country, and partly because the crop could be used to combat global food shortages, reducing household hunger and malnutrition, especially in developing countries.

Official Exchange rate (where N135 = 1US\$)

Number of year $=\mathrm{N}$, where $\mathrm{N}=10$.

Where, $\frac{\text { sum }}{\mathrm{N}}=$ Average Value

Result of years and price analysis as represented in (Figure 3) indicated increased in price owing to the high economic value of the crop. Gross increased observed in land area devoted to maize production presented the crop as one of the most important food crops in the country, thereby agreeing with the submission of Purseglove [1]; Osagie and Eka [2], were their research findings presented maize to be cultivated to a large areas of land, owning to the crop importance as one of the most widely utilized crop globally.

Table 1: Economic Contribution of Maize Production in Nigeria in Thousand Tonnes $(1980-1989)$

\begin{tabular}{|c|c|c|c|c|c|}
\hline Year & Maize & Total Grain & $\%$ of Maize & Area of Land Planted to Maize (Ha) & Price of Maize (N/ton) \\
\hline 1980 & 612 & 7026 & 8.7 & 5600 & 2500 \\
\hline 1981 & 720 & 7588 & 9.5 & 982200 & 3000 \\
\hline 1982 & 766 & 8108 & 9.4 & 130600 & 3000 \\
\hline 1983 & 594 & 7465 & 8 & 148800 & 3000 \\
\hline 1984 & $2,058.00$ & 10719 & 19.2 & 11200 & 3000 \\
\hline 1985 & $1,190.00$ & 10765 & 11.1 & 211600 & 3000 \\
\hline 1986 & $1,336.00$ & 12149 & 11 & 211700 & 7000 \\
\hline 1987 & $4,612.00$ & 15714 & 29.3 & 211760 & 7000 \\
\hline 1988 & $5,268.00$ & 19269 & 27.3 & 211740 & 10000 \\
\hline 1989 & $5,008.00$ & 22432 & 22.3 & 211740 & 14000 \\
\hline Sum & 22164 & 121235 & 155.8 & 2426940 & 55500 \\
\hline Average & 2216.4 & 12123.5 & 15.58 & 242694 & 5550 \\
\hline
\end{tabular}

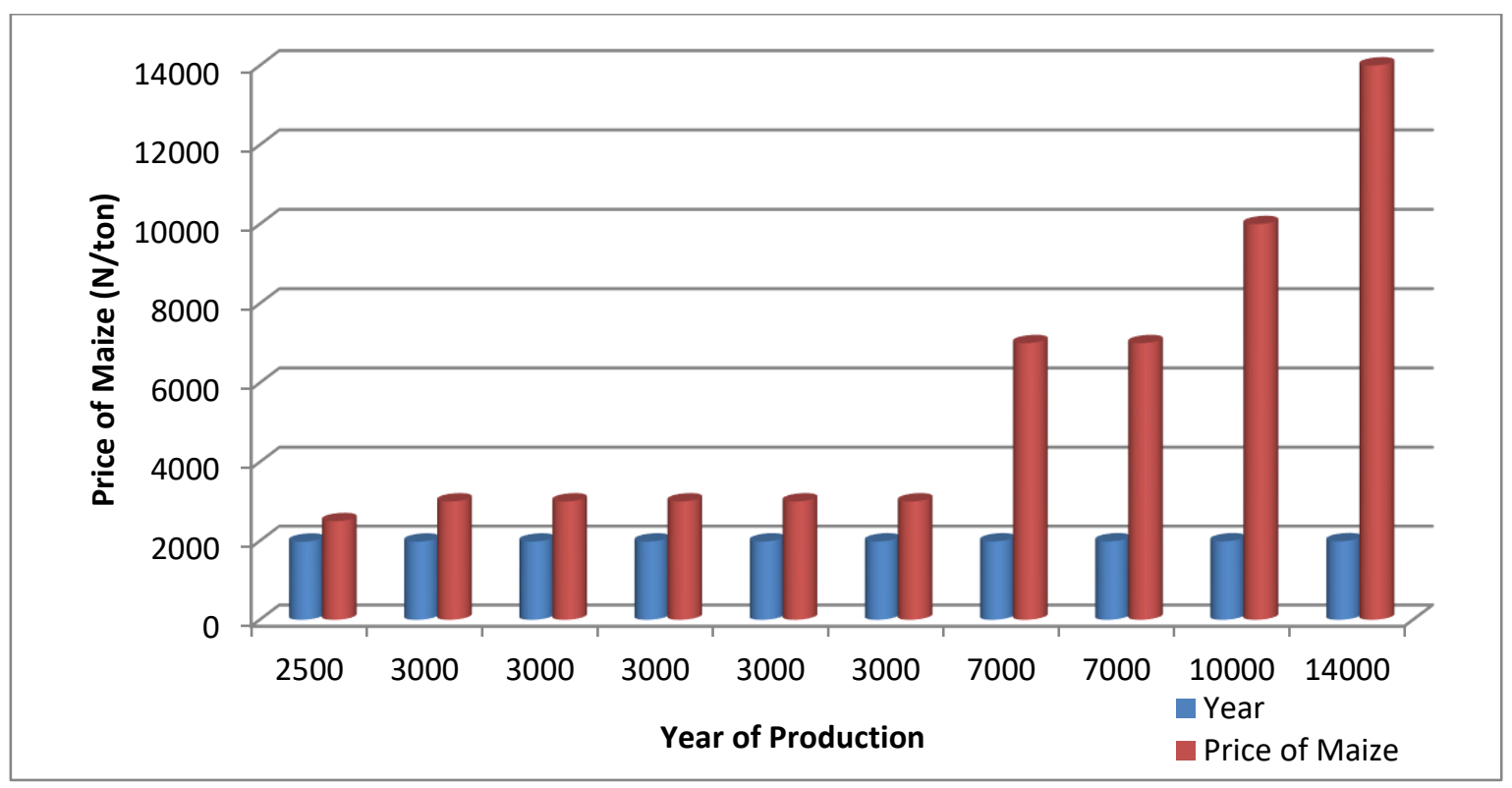

Fig. 3: Analyzed Price/Contribution of Maize to Nigerian Economy from (1980 - 1989). 
Table 2: Field Cropping Analysis of Contribution of Maize (Zea Mays L.) Grain Yield per Plot and Grain Weight to Increased Food Production and Economic Growth

\begin{tabular}{lll}
\hline Treatment & Weight of 100 grains $(\mathrm{g})$ & Grain Yield/ plot $(\mathrm{kg})$ \\
\hline Control & 25.00 & 0.925 \\
3 tha $^{-1}$ & 25.00 & 1.333 \\
6 tha $^{-1}$ & 50.00 & 1.450 \\
9 tha $^{-1}$ & 50.00 & 1.700 \\
12 tha $^{-1}$ & 83.00 & 1.691 \\
& & 0.227 \\
LSD $(\mathrm{p}<0.05)$ & 12.16 & \\
\hline
\end{tabular}

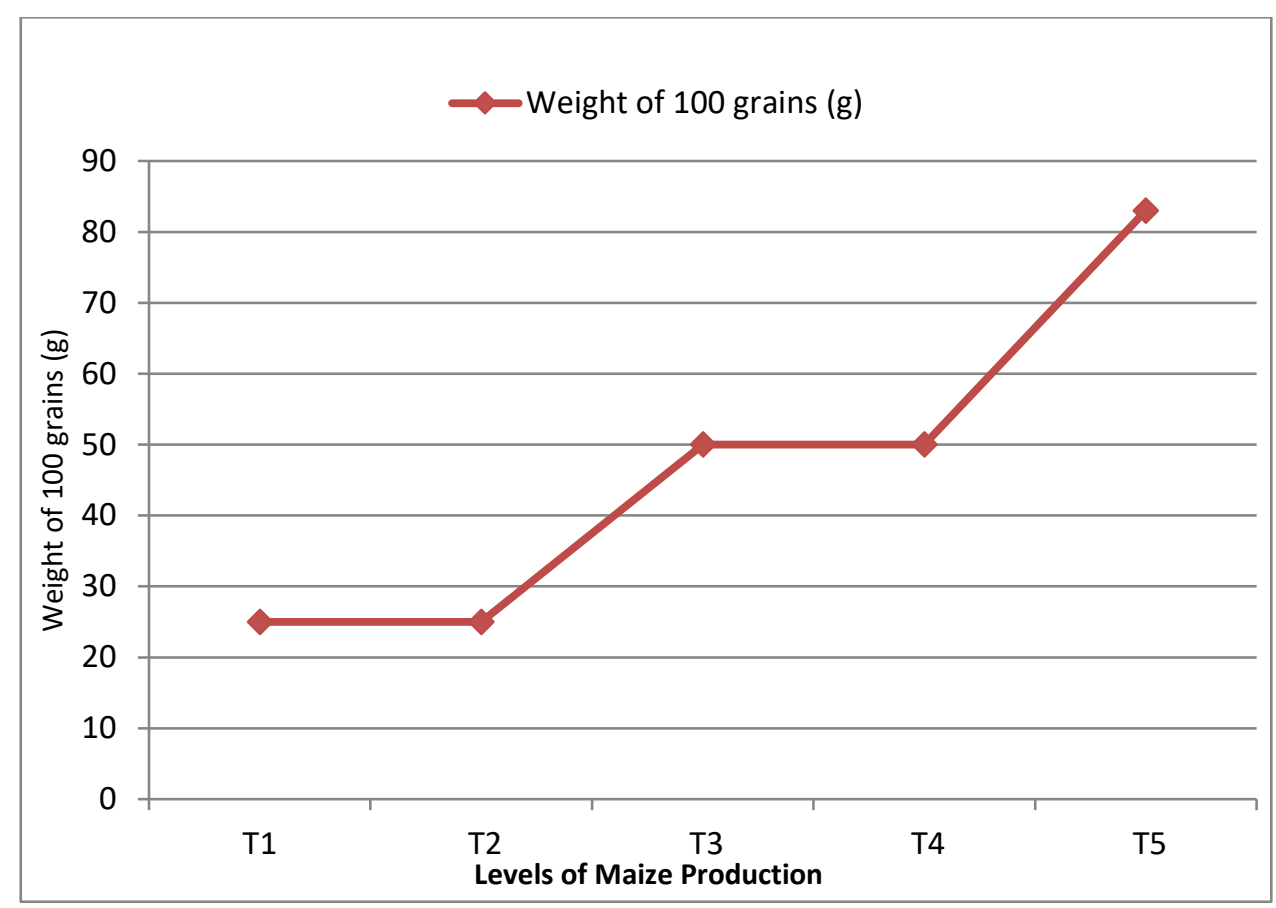

Fig. 4: Analyzed Weight of 100 Grains of Cultivated Maize (G).

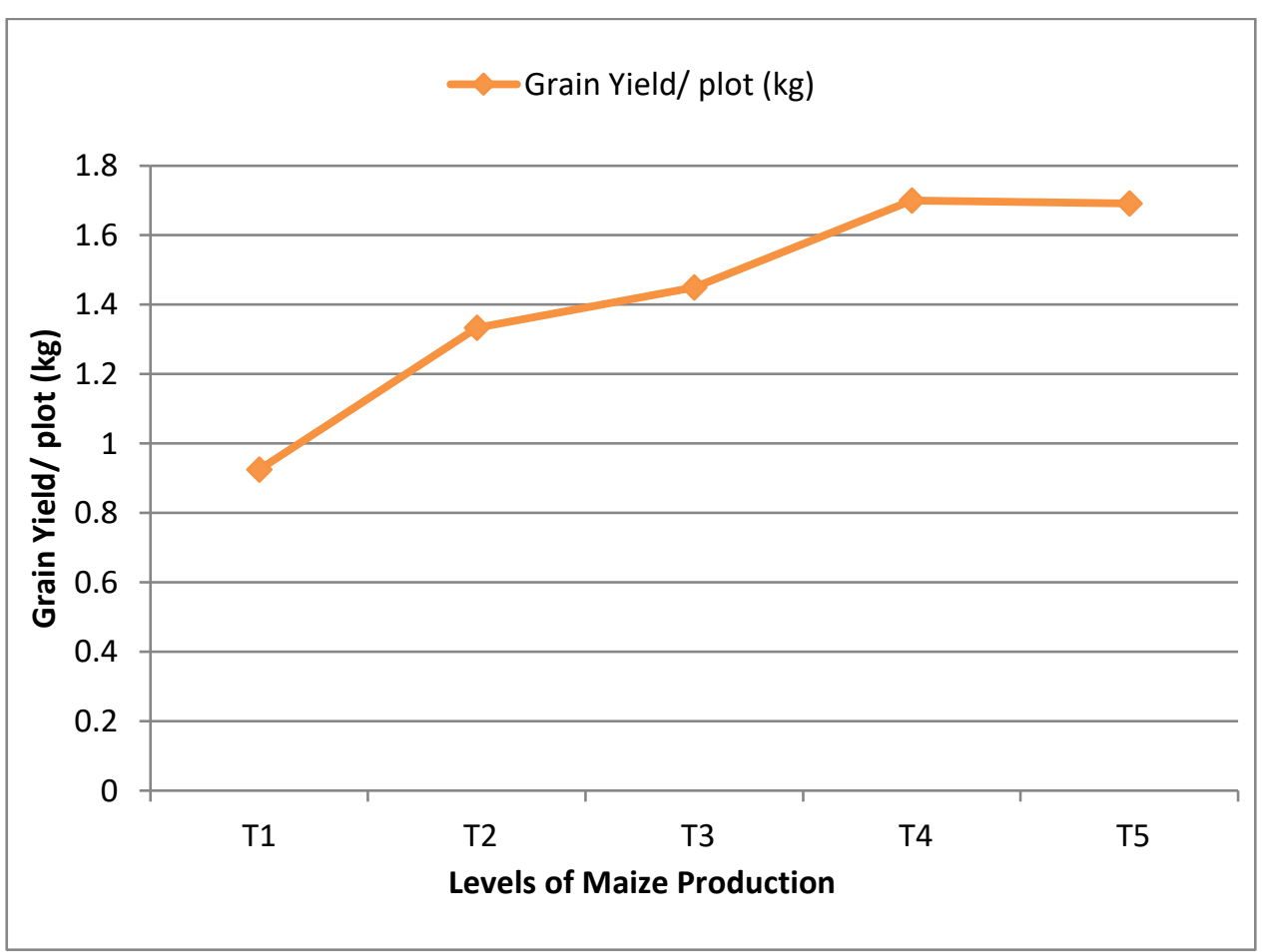

Fig. 5: Analyzed Grain Yield/ Plot (Kg) of Cultivated Maize (G).

Field result obtained after harvesting as presented in (Table 2, and represented in Figure 4/5) indicated that maize grain produced was significant $(\mathrm{p}<0.05)$, and stands over the control. Therefore confirming the survey of Hartmans [5], which presented maize to be widely cultivated across all agro-ecological zones of the country, in addition to the fact that the crop is one of the fast growing cash crops in Nigeria. The harvested maize cobs were given to the locals to further confirm the result of field trip. It was observed that 3 out of 5 locals who were given large quantities of maize sold the produce to generate income, while the other 2 where observed to use the produce as food for household feeding. This observation further confirms the research findings of Ayeni [7]; Degrande and 
Duguma [9], whose findings presented maize as having the potential to combat household hunger, apart from generation of income for the locals and foreign exchange earnings for the country.

Traditional utilization of maize has been surveyed by various researchers. Result of this investigation revealed maize stalk extract been used for treatment of gonorrhea, this findings also confirms the survey of AbdulRahaman [10], where the researcher reported the crop been active as herbal medication. In an herbal home surveyed, infusion obtained from stigma of maize inflorescence was observed to be used for treatment of urinary tract disorder. Water obtained from maize grain processing in wet flour, pap and other related product was observed to use for herbal treatment of fever and fever-related illness like malaria, this research findings further confirms the survey of AbdulRahaman and Kolawole [11]. Traditional maize utilization also include usage of maize grain by the local people of Obubra in charm making, which the locals believed can keep an individual safe from his enemies. Maize has been observed to be utilized in traditional rite, including traditional marriages, where parts of the crop is been used as a material for incantation to strongly unite/join two individual (couple) together.

\section{Conclusion}

Result of the survey proves that production, management, utilization and sales of maize have improved the economy of Nigeria. Analyzed data indicated that production of maize increased as the number of year increases, this could be probably due to the increased in human population and the ability of the crop to strive in all agro-ecological zones of the country. The survey on traditional utilization of maize indicated that maize has medicinal, spiritual, including dietary values, apart from serving as a means of income/foreign exchange earnings.

\section{Recommendation}

From the result of the study, it could be recommended that more hectares of arable land should be devoted to maize cultivation, owning to the fact that the crop has been found to be a multipurpose crop, serving not only as food, but as a part of the tradition of some of the African culture, while in-turn presenting an avenue were human/animal health can be maintain through it utilization in herbal traditional medicine, as feed for livestock management, and as raw material for industrial production.

\section{References}

[1] Purseglove, J. W. (1992). Tropical Crops: Monocotyledones Longman Scientific and Technical, New Yorrk. Pp. 300-305.

[2] Osagie, A. U. and Eka, O. U. [Eds.] (1998). Nutritional Quality of Plant Foods. Post-Harvest Research Unit, University of Benin, Benin. Pp. 34-41.

[3] Ihekoronye, A. L. and Ngoddy, P. O. (1965). Integrated Food Science and Technology for Tropics. Macmillan Publisher, Hong Kong. P. 386.

[4] Kochhar, S. L. (1986). Tropical Crops: A Texbook of Economic BOTANY. Macmillan Publishers, Hong Kong. Pp. 88-95.

[5] Hartmans, E. H. (1985). Strategies for Solving Crop Production Problems of Sub-Saharan Africa. International Institute of Tropical Agriculture, Ibadan, Nigeria $7-8$.

[6] IITA, International Institute of Tropical Agriculture (2014). Maize (Zea mays L.) production. http://www.iita.org/maize. Accessed April1 2013.

[7] Ayeni, A. O. (1991). "Maize Production in Nigeria: Problems and Prospects". Journal of Food and Agriculture, 2: 123-129.

[8] CBN, Central Bank of Nigeria (1992). Annual Report and Statement of Account. Central Bank of Nigeria, Lagos. P. 78.

[9] Degrande, A. and Duguma, B. (2000). Adoption Potential of Rotational row Intercropping in Humid and Extension Network (103): 17.

[10] AbdulRahaman, A. A. (1997). Medicinal Importance of Plant In: The Frontiers. $1^{\text {st }}$ ed. Edited by K. A. Omotoshe. Elepo Press. Ilorin. Pp. $22-25$.
[11] AbdulRahaman, A. A. and Kolawole, O. M. (2006). Traditional Preparations and Uses of Maize in Nigeria. Ethnobotanical Leaflets, 10: 219-227. 